\title{
CASES
}

\section{Guiding Principles for Directorial Conflicts of Interest: Re Allied Business and Financial Consultants Ltd; O'Donnell v Shanahan}

\author{
Deirdre Ahern*
}

The Court of Appeal has disposed of the 'scope of business' test as the touchstone principle for directorial entrepreneurship cases and has confirmed the continuing applicability of a capacity approach while emphasising the importance of directors obtaining the company's informed consent before taking up opportunities that they encounter. This provides welcome legal certainty but raises interesting questions about the scope of a director's disclosure obligations.

\section{INTRODUCTION}

The Court of Appeal's decision in Re Allied Business and Financial Consultants Ltd; O'Donnell v Shanahan ${ }^{1}$ (O'Donnell) examines directorial entrepreneurship, in particular, the thorny question of the test to be applied to determine whether a conflict of interest arises. The Court's reasoning provides a principled resolution of this difficult issue based on a strict, prophylactic approach. However, while relatively certain of application, opponents of this approach tend to highlight its failure to engage satisfactorily with the vexed question of what opportunities a company can legitimately lay claim to.

The legal interface between private business endeavour and fiduciary responsibilities is not an easy one. The appropriate test to be employed in determining whether a director is free to take up an opportunity encountered is a question that has divided courts and commentators over the years with a division between those favouring the capacity approach propounded in Regal (Hastings) Ltd $\mathrm{v}$ Gulliver ${ }^{2}$ (Regal (Hastings)) and those favouring a more flexible, fact-sensitive approach which seeks to categorise the opportunity as one in which the company would or would not have an interest. Opposing viewpoints have been at play in the ambivalence exhibited by the courts in relation to directors taking up business opportunities that they encounter in the course of their directorships. Nevertheless, the equivocation of the courts over the last number of decades in selecting an appropriate model for dealing with competitive activity by directors has led to a line of authorities exhibiting a variety of judicial approaches to key matters of legal principle.

Traditionally judges have expressed themselves to be unwilling to go behind a directorial profit in order to determine the level of culpability based on the surrounding circumstances including whether the company would have real

\footnotetext{
*Trinity College Dublin.

1 Re Allied Business and Financial Consultants Ltd; O'Donnell v Shanahan [2009] EWCA Civ 751; [2009] 2 BCLC 666. Rimer LJ delivered the judgment of the Court (Aikens and Waller LJJ concurring). Unless otherwise indicated all references in square brackets are to paragraphs in the judgment of Rimer LJ.

2 [1942] 1 All ER 378.
} 
potential to exploit the opportunity in question. The deterrent effect of stringent rules in this setting is long-acknowledged. Some regard the Keech v Sandford ${ }^{3}$ Regal (Hastings) approach as too harsh while others regard it as providing an appropriate deterrent which is clear and certain. This strict approach to pursuing opportunities is characterised as a capacity or status approach since it focuses merely on the opportunity arising qua director. ${ }^{4}$ Such an approach was exemplified in the renowned decision of the House of Lords in Regal (Hastings). However, in directorial entrepreneurship cases over the last few decades the English courts have alternated between the pragmatism of the corporate opportunity approach ${ }^{5}$ and a strict fiduciary, principle-led analysis. ${ }^{6}$ For a time the more expansive, maturing business opportunity analysis of the corporate opportunity doctrine provided a counterpoint to judicial adoption of the capacity approach and for a limited period it proved attractive to the English courts before the pendulum swung back in favour of a capacity approach. Indeed, while the trend of cases in the 1980s and 1990s was towards embracing a corporate opportunity analysis inspired by US and Canadian cases, ${ }^{7}$ in Bhullar v Bhullar ${ }^{8}$ (Bhullar) the burgeoning maturing business opportunity approach, which had gained a foothold in the lower courts, was dealt a seemingly fatal blow with the Court of Appeal making it clear that whether the company could be regarded as having a beneficial interest in the opportunity was 'too formalistic and restrictive an approach'. 9 . Most recently, a round endorsement of the capacity approach at Court of Appeal level in O'Donnell signifies that it is not appropriate to focus on the question of whether the opportunity exploited could be said rightfully to belong to the company based on either a maturing business opportunity test or a scope of business enquiry. The decision consolidated the trend in post-Bhullar case law to focus on informed consent to directorial entrepreneurship as the key touchstone in this area. ${ }^{10}$

The case also demonstrates the need for further consideration of the complex territory of the legal and practical boundaries of a duty-based obligation on directors to disclose information to the company. This terrain raises two distinct matters of concern - the duty on a director to disclose information in order to

3 (1726) Sel Cas Ch (Temp King) 25 ER 223.

4 See R. Edmunds and J. Lowry, 'The No Conflict-No Profit Rules and the Corporate Fiduciary: Challenging the Orthodoxy of Absolutism' [2000] JBL 122, 132; H. C. Hirt, 'The Law on Corporate Opportunities in the Court of Appeal: Re Bhullar Bros Ltd' [2005] JBL 669, 670.

5 Island Export Finance Ltd v Umunna [1986] BCLC 460; Balston v Headline Filters Ltd [1990] FSR 385; Framlington Group plc v Andersen [1995] 1 BCLC 475.

6 Industrial Development Consultants Ltd v Cooley [1972] 2 All ER 162; Gencor ACP Ltd v Dalby [2000] 2 BCLC 734; Ball v Eden Project Ltd [2002] 1 BCLC 313; Bhullar v Bhullar [2003] EWCA Civ 424; [2003] 2 BCLC 241; Crown Dilmunv Sutton [2004] EWHC 52 (Ch); [2004] 1 BCLC 468; Quarter Master UK Ltd (in liq) v Pyke [2004] EWHC 1815 (Ch); [2005] 1 BCLC 245.

7 Two Canadian cases were particularly influential - Peso Silver Mines Ltd v Cropper (1966) 58 DLR 1 and Canadian Aero Service Ltd v O’Malley [1974] SCR 592. On the corporate opportunity doctrine see D. D. Prentice,'The Corporate Opportunity Doctrine' (1974) 37 MLR 464; Edmunds and Lowry, n 4 above; S. Scott, 'The Corporate Opportunity Doctrine and Impossibility Arguments' (2003) 66 MLR 852.

8 n 6 above.

9 ibid at [28].

10 See, eg Crown Dilmun v Sutton [2004] EWHC 52 (Ch); [2004] 1 BCLC 468; Quarter Master UK Ltd (in liq) v Pyke n 6 above; Murad v Al-Saraj [2005] EWCA Civ 959; Kingsley IT Consulting Ltd v McIntosh [2006] EWHC 1228; [2006] BCC 875. 
obtain consent to what would otherwise be a breach of the duty to avoid conflicts of interest, and the related but distinct question of an expectation that a director disclose relevant information concerning corporate opportunities to the company where there is no intention of personal exploitation. These issues are of jurisprudential significance but also of considerable practical importance in commercial life.

\section{ANALYSIS}

\section{Factual background}

The salient facts of O'Donnell can be distilled to the essentials. The petitioner and the first and second respondents were equal shareholders and directors of a company run as a quasi-partnership providing investment advice and allied services. The petitioner presented an unfair prejudice petition under the then applicable section 459 of the Companies Act 1985 (now section 994 of the Companies Act 2006). The crux of the matter was whether the first and second respondents' acquisition of an interest in Aria House, a valuable investment property in central London, was in breach of the no conflict-no profit rules applicable to directors. The background was that an agent of the companies owning the property had approached the first respondent in relation to the property on the basis that he might have clients who would be interested in purchasing the property. He did not mention the company but shortly afterwards he became a client of the company. The first respondent had initially interested a client of the company in a long lease but this deal ultimately fell through at the eleventh hour. Another company client and his brother were prepared to take over the acquisition if the first and second respondents took a 50 per cent stake in the venture. A consequence of this was that the company missed out on a commission fee of $£ 30,000$ although the petitioner was later paid $£ 9,000$ to represent approximately her share of the lost commission. Although the opportunity had not come up for consideration by the company at the time, the trial judge made a finding of fact that at the time of the purchase the company could not have participated in a purchase of the property without receiving funding from its shareholders. The petitioner was found not to have sufficient funds to participate and also not to have a risk appetite for such an investment. At first instance, ${ }^{11}$ the trial judge, Richard Sheldon QC (sitting as a deputy judge of the High Court), held that there had been no breach of the no conflict-no profit rules while the Court of Appeal reversed and remitted to the trial judge the question of whether the failure to account to the company for any profit was unfairly prejudicial to the petitioner.

\section{The conflict - profit taxonomy}

Both the trial judge and the Court of Appeal recognised a bifurcation between the no conflict and the no profit rules, a division which had been increasingly appreciated by the courts in recent years. This taxonomy is not directly replicated

11 [2008] EWHC 1973 (Ch); [2009] 1 BCLC 328. 
in the Companies Act 2006; section 175 provides a duty to avoid conflicts of interest which many commentators regard as largely subsuming the no profit rule. ${ }^{12}$ This is evident in section 175(2)'s reference to the duty applying to 'the exploitation of any property, information or opportunity'. There is, however, a related duty not to accept benefits from third parties in section 176. The better view appears to be that section 176 should not be regarded as an equivalent of the preexisting no profit rule. Section 175 encompasses profits as well as conflicts while section 176 is more limited in scope and was based on pre-existing equitable principles relating to bribes and secret commissions. Furthermore, unlike section 175 , section 176 contains no authorisation mechanism for infringing acts. This in itself lends weight to a narrow interpretation of its scope.

\section{Treatment of the 'scope of business' test}

At the heart of both the trial judge and the Court of Appeal's decisions was the relevance of a scope of business enquiry to determine whether a breach of the no conflict rule had occurred. The concept of an interest which 'possibly may conflict' with the interests of the company can be traced back to Lord Cranworth's seminal pronouncements in Aberdeen Railway Cov Blaikie Bros, ${ }^{13}$ adapting trustee fiduciary principles to a corporate context. ${ }^{14}$ Subsequent case law provided a handle on how this test should be objectively interpreted. ${ }^{15}$ A particular milestone was Upjohn LJ's advocacy in Boulting v Association of Cinematograph, Television and Allied Technicians $^{16}$ of a common sense approach which focused on 'real conflict of interest and duty, and not ... some theoretical or rhetorical conflict. ${ }^{17}$ The trial judge's application of a scope of business test derived from the 'real sensible possibility of conflict test' subsequently propounded by Lord Upjohn in Boardman v Phipps ${ }^{18}$ where he interpreted Lord Cranworth's reference to 'possibly may conflict' as requiring that a reasonable man would think that there was a real sensible possibility of conflict.' ${ }^{19}$ This is now reflected in section 175(4)(a) of the Companies Act 2006 which indicates that the no conflict duty will not be breached 'if the situation cannot reasonably be regarded as likely to give rise to a conflict of interest'.

12 B. Hannigan and D. Prentice (eds), Hannigan and Prentice: the Companies Act 2006 - A Commentary (Edinburgh: Lexis Nexis Butterworths, $2^{\text {nd }}$ ed, 2009) para 4.1; G. Morse (ed), Palmer's Company Law: Annotated Guide to the Companies Act 2006 (London: Thomson Sweet \& Maxwell, 2007) 171; S. Mortimore (ed), Company Directors: Duties, Liabilities and Remedies (Oxford: Oxford University Press, 2009) paras 14.12, 14.37; J. Birds and A. J. Boyle, Boyle \& Birds' Company Law (Bristol: Jordans, $7^{\text {th }}$ ed, 2009) paras $16.8 .1,16.9$.

13 [1843-1860] All ER Rep 249.

14 ibid, 252.

15 See Boulting v Association of Cinematograph, Television and Allied Technicians [1963] 1 All ER 716, 730, per Upjohn LJ; Boardman v Phipps [1967] 2 AC 46, 124, per Lord Upjohn; Wilkinson v West Coast Capital [2005] EWHC 3009 (Ch); Bhullar v Bhullar n 6 above; Re Allied Business and Financial Consultants Ltd; O’Donnell v Shanahan [2008] EWHC 1973 (Ch); [2009] 1 BCLC 328.

16 [1963] 1 All ER 716.

17 ibid, 730.

18 [1967] 2 AC 46.

19 ibid, 124. 
The practical application of this test was elucidated by Warren $\mathrm{J}$ in Wilkinson $\mathrm{v}$ West Coast Capital $^{0}$ (Wilkinson) where he stated that, in applying the no conflict rule, one should have regard to both the scope of the director's duties and the scope of the company's business. Warren J noted that, while a widely drafted objects clause would permit all manner of diversification by a company, there would, for example, be no real sensible possibility of conflict were a director of a company selling women's fashion to take a stake in a company that distributed farm machinery unless diversification into this line of activity was being actively considered by the company. ${ }^{21}$ This line of reasoning proved most influential at first instance in O'Donnell but, on appeal, the Wilkinson scope of business argument had little purchase.

The trial judge ruled that although the opportunity to acquire the property came to the first and second respondents in their capacity as directors, it was outside the scope of the company's business. As the company's business was viewed as concentrated on providing financial and business advisory services, the acquisition of properties for investment was not treated as being within the scope of the company's business and consequently it was held that there was no breach of the no conflict rule and no breach of the no profit rule. It was emphasised that it was not contemplated by the directors that the company would diversify into property investment and it was therefore concluded, applying Wilkinson, that there was no real sensible possibility of conflict. Furthermore, taking up the opportunity would have required the raising of finance from the company's shareholders, which the petitioner was unlikely to have provided. An appeal to the Court of Appeal was successful and significantly, the nub of the Court of Appeal's reasoning was a rejection of the scope of business enquiry as the relevant legal test.

The Court of Appeal treated the scope of business approach as redundant and instead presented a more pro-company approach than the entrepreneurshipfriendly scope of business test which had previously found favour. Why the divergence of approach? Differing views were exhibited in the High Court and Court of Appeal in relation to the relevance of Aas $\mathrm{v}$ Benham, ${ }^{22}$ a case in relation to the competing activities of a partner in a firm of shipbrokers where the Court of Appeal used a scope of business test as a guiding precept. The trial judge favoured the Aas v Benham approach (which had been a central plank in Wilkinson) being readily applied to the application of the no conflict rule to directors. However, the Court of Appeal dismissed the relevance of this authority in relation to fiduciaries such as trustees and directors whose duties and activities are not circumscribed by a contract in the nature of a partnership agreement. By contrast, in the instant corporate context, the company's constitution did not preclude property investment as an object. This was an appropriate handling of Aas $\mathrm{v}$ Benham given that the closely circumscribed contractual undertaking of a partner differs from the far more general duty on a director to act in good faith in the best interests of the company, now reformulated as a statutory duty to act to promote the success of

20 [2005] EWHC 3009 (Ch); [2007] BCC 717 at [252]-[253].

21 ibid at [253].

22 [1891] 2 Ch 244. 
the company in section 172 of the Companies Act 2006. Furthermore, companies nowadays are likely to have either unlimited capacity, pursuant to section 31(1)'s removal of the requirement for an objects clause, or else a very broadly drafted general objects clause providing a close equivalent to unrestricted capacity. Therefore the partnership analogy is not an apt one.

The challenge of applying a scope of business test in practice lies in the artificiality of attempting to draw lines around a company's potential future scope of business. Indeed, while the trial judge had acceded to the argument that the company's scope of business did not extend to estate agency, Rimer LJ correctly turned this argument on its head by noting that the engagement of the company (acting through Mr Shanahan) to find a purchaser for Aria House was the company's first foray into the avenue of estate agency, thereby demonstrating that at that point, the company's categories of activities were not closed. This was sensible on the facts and accords with companies being essentially expansionist in nature when appropriate opportunities arise. The risk-taking role of directors in generating corporate wealth is well-acknowledged and, as such, differs from the prudent asset management role of trustees. Thus in the leading US case on the corporate opportunity doctrine, Guth v Loft, Inc, ${ }^{23}$ (Guth v Loft) it was sagely asserted by the Supreme Court of Delaware that to deny the expansionist nature of corporations would be 'to deny the history of industrial development'. ${ }^{24}$ That being said, there is a danger that unless some boundaries are assumed concerning a company's expansion, every opportunity encountered by a director is effectively regarded as a potential corporate opportunity requiring disclosure to the company before it can be exploited. ${ }^{25}$ On the other hand, this is precisely what proponents of a strict capacity approach advocate so as to encourage loyalty to the company, and this rationale underpins O'Donnell.

Some commentators have argued for the adoption of a more nuanced approach inspired by the corporate opportunity doctrine favoured in some US states, which frequently incorporates a 'line of business' test. ${ }^{26}$ Thus, while the Wilkinson scope of business test might be seen to be a relatively blunt instrument, a more sophisticated approach is evident in a line of business test which looks beyond an existing commercial interest or expectancy in the relevant opportunity. ${ }^{27}$ The Delaware Supreme Court has favoured a multi-faceted corporate opportunity standard centred on the opportunity being within the line of business to which the corporation could adapt itself. In the influential Guth v Loft decision the Delaware Supreme Court stated:

Where a corporation is engaged in a certain business, and an opportunity is presented to it embracing an activity as to which it has fundamental knowledge, practical experience and ability to pursue, which, logically and naturally, is

235 A2d 503 (Del 1939).

24 ibid 514. See also Scott, $\mathrm{n} 7$ above, 858-859.

25 Scott ibid, 859 .

26 SeeJ. Lowry and R. Edmunds, 'The Corporate Opportunity Doctrine: The Shifting Boundaries of the Duty and its Remedies' (1998) 61 MLR 515; Edmunds and Lowry, n 4 above.

27 On the interest or expectancy approach see, eg Lagarde v Anniston Lime \& Stone Co 28 So. 199 (Ala. 1900). 
adaptable to its business ... and is one that is consonant with its reasonable needs and aspirations for expansion, it may be properly said that the opportunity is in the line of the corporation's business. ${ }^{28}$

The line of business test considers the company's financial ability to take up an opportunity to be a relevant consideration, ${ }^{29}$ a matter which was treated as irrelevant in O'Donnell. The line of business test is also an integral part of the American Law Institute's definition of a corporate opportunity as part of its corporate governance project, which is designed to assist clarity given the disparate approaches which are in existence across the US. A corporate opportunity is defined by the American Law Institute (ALI) as one that comes to a director or senior executive in connection with the performance of their functions or in such a way as reasonably to lead them to conclude that the person offering the opportunity expects it to be disclosed to the company (a modified capacity approach) ${ }^{30}$ or where a senior executive knows an opportunity is closely connected to a business in which the company is engaged or expects to engage. ${ }^{31}$ This latter type of approach, which has been described as an 'intermediate line-of business test', ${ }^{32}$ has no place in cases within the pure capacity mould.

\section{CAPACITY AS THE GUIDING PRECEPT}

O'Donnell qualifies previous guidance from the Court of Appeal in Bhullar where the 'real sensible possibility of conflict' test was preferred. O'Donnell takes this analysis up a notch in expecting all opportunities encountered in the course of a directorship to be disclosed to the company. In a classic application of Regal (Hastings), the fact that the company could not have taken up the opportunity without shareholder finance - which was unlikely to be forthcoming from the petitioner - was treated as irrelevant. This analysis is consistent with other post-Bhullar cases such as Quarter Master UK Ltd (in liq) v Pyke 33 where it was held that a conflict of interest arose even though the company would not have been in a position to take advantage of the business opportunity as it was going into liquidation. Here the ability to retain a profit was also predicated on obtaining the informed consent of the company. These cases reveal a firm rejection of the relevance of what is known as the impossibility argument' beloved of proponents of the corporate opportunity doctrine - the impossibility of the company taking up the relevant opportunity. ${ }^{34}$ This approach

28 n 23 above, 514 .

29 See eg, Broz v Cellular Information Systems Inc 673 A2d 148 (Del 1996).

30 American Law Institute, Principles of Corporate Governance: Analysis and Recommendations (St Paul, Minnesota: American Law Institute Publishers, 1994) §5.05(b)(1). For judicial adoption of the ALI reformulation see Klinicki v Lundgren 280 Or 662, 695 P2d 906, 917-18 (1985); Tennessee Bearing and Supply, Inc v Parish 1988 WL 122337 (Tenn App).

31 Principles of Corporate Governance ibid, $\$ 5.05(\mathrm{~b})(2)$.

32 E. Talley,'Turning Servile Opportunities to Gold: A Strategic Analysis of the Corporate Opportunities Doctrine' (1998-1999) 108 Yale LJ 272, 290.

33 n 6 above.

34 For an endorsement of the more flexible Delaware appoach to impossibility arguments see Edmunds and Lowry, $\mathrm{n} 4$ above. 
confirms the rejection in Bhullar of the flexibility of the corporate opportunity doctrine, in the process removing the need for value judgments concerning whether taking up an opportunity represents an unacceptable diversion of a corporate opportunity as opposed to healthy entrepreneurship. Consequently, the Court of Appeal has ushered in a more black and white position than the previously more nuanced approach to conflict based on a real sensible possibility of conflict.' Although likely to divide commentators, the approach taken brings to mind Lord Mansfield's observation in Vallejo $\mathrm{v}$ Wheeler ${ }^{35}$ that in all mercantile transactions the great object should be certainty: and therefore, it is of more consequence that a rule be certain, than whether the rule is established one way or the other. ${ }^{36}$

In adopting a strict approach to opportunities encountered as a director, O'Donnell prefers capacity as the guiding precept over malleable concepts of fairness and corporate opportunity. The hard line approach taken to directorial entrepreneurship confirms the continuing relevance of the principled rigour of Keech $\mathrm{v}$ Sandford. It also echoes Bray v Ford" where Lord Herschell stated, '[i]t is an inflexible rule of a Court of Equity that a person in a fiduciary position . . . is not, unless otherwise expressly provided, entitled to make a profit; he is not allowed to put himself in a position where his interest and duty conflict. ${ }^{38}$ A passage in his judgment contains an enlightening discussion concerning the rationale behind the no conflict rule which captures its normative function in creating standards of best practice, reflected in the fact that an element of moral turpitude is not required in order to trigger its application:

It does not appear to me that this rule is, as has been said, founded upon principles of morality. I regard it rather as based on the consideration that, human nature being what it is, there is danger, in such circumstances, of the person holding a fiduciary duty being swayed by interest rather than duty, and thus prejudicing those whom he was bound to protect. It has, therefore, been deemed expedient to lay down this positive rule. But I am satisfied that it might be departed from in many cases, without any fear of breach of morality, without any wrong being inflicted, and without any consciousness of wrong-doing. ${ }^{39}$

Consistent with this, in O'Donnell Rimer LJ stated:

the rationale of the 'no conflict' and no profit' rules is to underpin the fiduciary's duty of undivided loyalty to his beneficiary. If an opportunity comes to him in his capacity as a fiduciary, his principal is entitled to know about it. The director cannot be left to make the decision as to whether he is allowed to help himself to its benefit. ${ }^{40}$

It is likely that the O'Donnell approach will continue to prove influential in cases arising under section 175 of the Companies Act 2006 as the courts are expected to have regard to pre-existing equitable principles in their interpretation. ${ }^{41}$ Indeed,

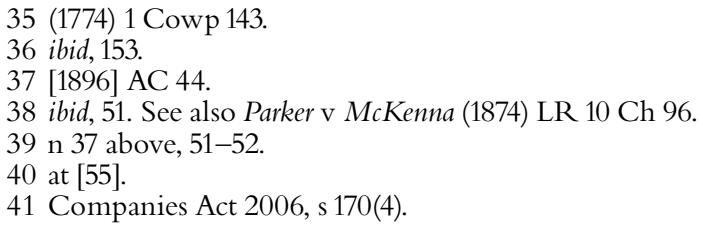


section 175(1) embodies the familiar test of 'a direct or indirect interest that conflicts, or possibly may conflict with that of the company' while sub-section (2) highlights that whether the company could take advantage of the opportunity is irrelevant. That being said, it will be interesting to see how section 175(4)(a)'s caveat that the duty is not infringed if the situation cannot reasonably be regarded as likely to give rise to a conflict of interest' will be interpreted in the future. This provision could give some scope for a more nuanced judicial approach than that evident in O’Donnell.

\section{DISCLOSURE OBLIGATIONS OF DIRECTORS}

One of the most jurisprudentially interesting aspects of the case relates to the emphasis on the importance of directors disclosing relevant information to the company. At the heart of the Court of Appeal's decision is the disclosure principle - once an opportunity comes to a director it should be disclosed to the company. The Court's view was that once the opportunity had arisen in a directorial capacity, it should have been disclosed to the company and if the company did not intend to take it up, the members could consent to it being taken up in a personal capacity by the directors. ${ }^{42}$

When it comes to a director's obligation to disclose information to the company, two independent questions arise. The first concerns the requirement to disclose in order to obtain authorisation to exploit an opportunity so as to avoid what could otherwise constitute a breach of the duty to avoid conflicts of interest. The second concerns the issue of the existence of a duty-based obligation on directors to disclose matters to the company which are of relevance to the company even where there is no intention personally to exploit the relevant information.

In relation to the first, O'Donnell indicates that it is not up to a director to determine whether the company could or would have taken up an opportunity - the opportunity should be disclosed to the company. This is implicit in Rimer LJ's statement that '[i]t may have been improbable that the company could or would want to be able to take up the opportunity itself. But the opportunity was there for the company to consider and, if so advised, to reject and it was no answer to the claimed breach of the 'no profit' rule that property investment was something that the company did not do. ${ }^{43}$ Somewhat controversially, this suggests a pseudoproprietary analysis which seeks to contain within its grasp all opportunities and information which a director encounters while holding that office. One cannot help but regard this as effectively giving the company a right of first refusal in respect of all opportunities which come a director's way. ${ }^{44}$ Rimer LJ emphasised the company's role in deciding whether the director could take up an opportunity in stating that '[i]f an opportunity comes to him in his capacity as a fiduciary, his

42 Section 175(5) of the Companies Act 2006 now permits authorisation by the board. The need for informed consent based on disclosure of all the material facts also precluded a defence of acquiescence as all material facts were not found to be known to Ms O'Donnell.

43 at [71].

44 On this point in a US context see J. Ying, 'Guth v Loft: The Story of Pepsi-Cola and the Corporate Opportunity Doctrine' (8 May 2009) 30 at http://ssrn.com/abstract=1414478 (last visited 9 February 2011). 
principal is entitled to know about it. The director cannot be left to make the decision as to whether he is allowed to help himself to its benefit. ${ }^{45}$ This is reminiscent of the Massachusetts case of Demoulas v Demoulas Supermarkets, Inc ${ }^{46}$ where the court stated that:

to ensure fairness to the company, opportunities must be presented to the company without regard to possible impediments, and material facts must be fully disclosed, so that the company may consider whether and how to address these obstacles ... Without such a rule, the fiduciary's self-interest may cloud his judgment or tempt him to overlook his duties. ${ }^{47}$

This point is returned to later in Rimer LJ's judgment where he forcefully states:

The point is that the existence of the opportunity is one that it is relevant for the company to know and of which the director has a duty to inform it. It is not for the director to make his own decision that the company will not be interested and to proceed, without more, to appropriate the opportunity to himself. His duty is one of undivided loyalty and this is one manifestation of how that duty is required to be discharged. ${ }^{48}$

In line with the capacity approach, this focus on the duty of loyalty serves to draw the focus away from the need for a qualitative analysis of the nature of the opportunity vis-à-vis the company's interests and capabilities.

Moving away from a situation of a directorial interest in personally exploiting an opportunity, the second issue in relation to disclosure relates to the existence of a broader duty to disclose information or opportunities to the company irrespective of any exploitative intent on the part of a director. The Court of Appeal was not required to consider this or other disclosure issues considered in other corporate opportunity cases.

The notion of a positive duty of disclosure in this context is a somewhat murky legal territory given the traditional understanding that fiduciary duties are proscriptive rather than prescriptive in nature. ${ }^{49}$ Modern judicial treatment stems from Item Software (UK) Ltd v Fassihi ${ }^{50}$ where Arden LJ recognised an affirmative duty on a director to disclose his own misconduct, ${ }^{51}$ which was said to be founded upon 'the fundamental duty' of directors to act bona fide and in the best interests of the company. ${ }^{52}$ Subsequently, a duty to disclose which extended beyond

45 at [55].

46677 NE2d 159 (Mass 1997).

47 ibid, 181.

48 at [70].

49 See further A. Cloherty, 'Directors' Duties of Disclosure' [2005] JBL 252; R. Lee, 'Rethinking the Content of Fiduciary Obligation' (2009) 3 Conv 236.

50 [2004] EWCA Civ 1244; [2005] 2 BCLC 91.

51 Support was drawn from a number of first instance decisions including Tesco Stores Ltd v Pook [2003] EWHC 823 (Ch); [2004] IRLR 618 and Crown Dilmun v Sutton [2004] EWHC 52 (Ch); [2004] 1 BCLC 468.

$52 \mathrm{n} 50$ above at [41]. Interestingly the reasoning in Item Software was regarded as wholly inadequate by Hollingworth J of the Supreme Court of Victoria in P E V Industries Pty Ltd v Porto [2006] VSC 131. See also the forcefully argued criticisms in L. Ho and P. Lee, 'A Director's Duty to Confess: A Matter of Good Faith?' (2007) 66 CLJ 348. 
misconduct was contemplated in Bhullar ${ }^{53}$ where Parker LJ concisely expressed the view that a duty to communicate information to the company would be triggered where a director is aware of the existence of an opportunity which it is 'relevant for the company to know' ${ }^{54}$ In Bhullar this was applied to the discovery of the availability of a property adjacent to the company's premises on a day off. Bhullar hinted at the possibility of a broad duty of disclosure, which could apply even in circumstances where the director had no intention of taking any steps to exploit the relevant business opportunity which had come to his or her attention. The legal basis for Parker LJ's pronouncements was unclear as they were not supported by authority and consequently the legal foundation for an all-embracing duty to disclose business opportunities to the company was questioned. ${ }^{55}$

Some clarity later emerged in Shepherds Investments Ltd $\mathrm{v}$ Walters ${ }^{56}$ where Etherton J dismissed the existence of an independent duty of disclosure. The duty to disclose misconduct and information 'of relevance and concern' to the company was regarded as simply an aspect of the duty to act in good faith and in the best interests of the company. ${ }^{57} \mathrm{~A}$ disclosure obligation of this nature could indeed more comfortably be taken to rest on an expansive interpretation of the duty to act in the best interests of the company (now reformulated in section 172 of the Companies Act 2006 as the duty to promote the success of the company) since a positive duty of disclosure would go against the grain of the essentially negative duty to avoid conflicts of interests. ${ }^{58}$ This is an interesting terrain which awaits further pronouncements of the Court of Appeal and Supreme Court in an appropriate case as the legal provenance and outer boundaries of an obligation to disclose matters of concern to the company outside the context of competing activity and preparatory steps thereto were not called upon to be addressed by the Court of Appeal in O'Donnell.

\section{CONCLUSION}

Looked at in context, O'Donnell represents the latest in a long line of vacillation by judges at varying levels in cases in the English courts concerning directorial entrepreneurship. This is linked to the inherent tension between strict fiduciary principles on the one hand, and public policy against restraint of trade, on the other. The bright-line fiduciary principles enunciated by the Court of Appeal are defensible as a means of providing certainty in this area and are, at base, far from novel, but rather represent a return to prophylactic fiduciary principle at its most strict. The focus on loyalty as the underpinning thread is in tune with the principle that directors must serve 'one master - the company. ${ }^{59}$ In this landscape, categorising the opportunity as one which the company would be interested in or capable of taking advantage of is irrelevant. The clear import of the Court of Appeal's

\footnotetext{
53 n 6 above.

54 ibid at [41].

55 Hirt, $\mathrm{n} 4$ above, 677-678.

56 [2006] EWHC 836 (Ch); [2007] 2 BCLC 202.

57 ibid at [132].

58 See further Hirt n 4 above, 678-679; P E V Industries Pty Ltd v Porto [2006] VSC 131 at [32] - [34], [43].

59 Dawson International plc v Coats Paton plc [1989] BCLC 233, 243, per Lord Cullen.
} 
endorsement of the capacity approach is that where an opportunity is presented to a director, the opportunity should be disclosed to the company for its decision on whether the director should be permitted to exploit it.

For proponents of the capacity approach a strict rule provides a deterrent function and any perceived harshness is tempered by the freeing effect of prior disclosure and consent. This does not address the possibility of the unwarranted blocking of directorial entrepreneurship based on an overly expansive notion of what is required to promote the success of the company, but that is an inescapable hazard of the judiciary's traditional 'softly, softly' approach to subjective directorial assessments of what is in the best interests of the company, ${ }^{60}$ now encapsulated in section 172(1) of the Companies Act 2006. From this perspective, given the right of first refusal which prudent directors must now extend to the company in respect of opportunities encountered, O'Donnell represents a not inconsiderable triumph for companies over the director class and its reverberations are likely to be widely felt.

\title{
Public or Personal Character in Election Campaigns: A Review of the Implications of the Judgment in Watkins v Woolas
}

\author{
Francis Hoar*
}

Reviewing the Election Court's decision that a candidate's parliamentary election literature was unlawful under the Representation of the People Act, the Divisional Court held that statements could either be about a candidate's public character or his personal character but not both. Though the legislation was compatible with the ECHR if it penalised only the latter, the question for the courts is really a matter of whether statement impugns a candidate's character more than merely as a necessary implication of an allegation regarding conduct such as the breaking of election promises.

It was the first time in 100 years that a court has thrown a sitting MP out of the House of Commons. On 5 November 2010 the Parliamentary Election Court handed down judgment declaring former Labour minister Phil Woolas's 2010 parliamentary campaign to have been unlawful and the election null, ordering a re-election and banning him from standing for elected office for three years. The case has galvanised the political establishment and led to many questions about the limitations of lawful campaigning in elections. ${ }^{1} \mathrm{Mr}$ Woolas brought a judicial review of the Parliamentary Election Court's decision on 3 December 2010. The Divisional Court upheld the decision, albeit on somewhat different grounds, it having been accepted that no appeal lay against the Election Court's finding of

60 Re Smith \& Fawcett Ltd [1942] Ch 304.

*Field Court Chambers.

1 Watkins v Woolas [2010] EWHC 2702 (QB) at http://www.judiciary.gov.uk/Resources/JCO/ Documents/judgments/judgment-oldham-election-05112010.pdf (last visited 18 April 2011). 
Copyright of Modern Law Review is the property of Wiley-Blackwell and its content may not be copied or emailed to multiple sites or posted to a listserv without the copyright holder's express written permission. However, users may print, download, or email articles for individual use. 